\title{
USE OF METHANE-FREE SYNTHESIS GASES AS FUEL IN AN SPARK IGNITION COMBUSTION ENGINE
}

\author{
CHRÍBIK Andrej ${ }^{*}$, POLÓNI Marián ${ }^{1}$, MINÁRIK Matej ${ }^{1}$ \\ ${ }^{I}$ Slovak University of Technology in Bratislava, Faculty of Mechanical Engineering, Institute of Transport \\ Technology and Engineering Design, Námestie slobody 17, 81231 Bratislava, Slovakia, \\ e-mail: andrej.chribik@stuba.sk
}

\begin{abstract}
The presented article deals with the use of methane-free synthesis gases in a spark-ignition internal combustion engine. The authors analyse the influence of seven synthesis gases on integral as well as internal parameters of the engine and make comparisons with operation on methane. The main combustible components of the synthesis gas are hydrogen and carbon monoxide and the remainder are inert gases (nitrogen and carbon dioxide). At the operating speed of the combustion engine of $1500 \mathrm{rpm}$, at which the cogeneration unit operates, in comparison with methane a decrease in power parameters was recorded in the range from 19 to $35 \%$. The increase in the hourly fuel consumption was 6 to 8 times higher. Depending on the gas composition, the optimum start of ignition angle at full load ranged from 17 to $26^{\circ} \mathrm{CA}$ BTDC. In terms of analysis of internal parameters, the cyclic variability of the pressure in the engine cylinder, which characterizes the stability of its operation, was in synthesis gases operation mostly at a lower level (from 3.6\% to 6.9\%) than in methane operation (6.8\%). Due to the presence of hydrogen, the main combustion time interval of all synthesis gases has been shorter compared to methane. The presented results serve to better understand the setting of the waste gasification process so that the highest possible energy and economic recovery in the cogeneration unit is obtained.
\end{abstract}

KEYWORDS: internal combustion engine, synthesis gases, mass fraction burned, analysis of pressure

\section{Introduction}

The aim of the presented article is to offer the reader a basic analysis of the possibility of using methane-free synthesis gases in a spark-ignition internal combustion engine. The use of synthesis gases is one of the alternatives to make efficient use of waste management in order to eliminate the negative impact on the environment. Waste management is also an important factor in environmental protection. In 2018, 13478036 tons of waste were generated in the Slovak Republic. Of this amount, a total of 3344077 tons were landfilled, representing $24.8 \%$. The production of municipal waste in 2018 reached a level of 2325178 tons. The most common 1, Environmental Strategy 2030, the Slovak Republic is committed to reducing the landfill rate to $25 \%$ by 2035 [1]. One of the possible ways to achieve such goals is the gasification of waste and conversion of waste into synthesis gases (SG). The purpose of such gasification may be direct energy recovery in cogeneration units. However, such a system must be available locally, especially for large customers outsourcing electricity and waste heat from the internal combustion engines. The problem with gasification and the use of the energy potential of gasified waste is the consequent high cost of transporting large amounts of waste to the gas producer [2]. Compared to direct combustion in incinerators, the advantage of the gasification process is a lower production of emissions both gaseous and solid [3, 4]. Another important aspect typical of environmental protection during direct gasification is the prevention of landfill gas formation. The landfill gas formation takes place in 4 phases (aerobic, anaerobic decomposition, fast and subsequently slow methane production). Even with the high quality of such a gas (methane content up to 60\%), with slowly decomposing 
waste the half-lifetime of decomposition can reach up to 40 years [5, 6]. Such a slow recovery is ecologically advantageous, for example in handling of used tires [7, 8]. The composition of synthesis gases from waste depends mainly on the input of raw material, as well as on the method of its processing. The main components of such gases are in particular methane, carbon dioxide, carbon monoxide, hydrogen and nitrogen. Prior to processing, it is necessary to purify the synthesis gases, especially of tars and water vapour. Tars cause clogs in the narrow spaces of internal combustion engine, and also in filters $[9,10]$. The amount of tars in the fuel in internal combustion engines should not exceed $0.01 \%$ by volume, which corresponds to a value of $10 \mathrm{mg} / \mathrm{Nm}^{3}$. At values above $30 \mathrm{mg} / \mathrm{Nm}^{3}$, the operation of an internal combustion engine becomes problematic [11].

The main goal of the presented paper is to evaluate the performance, economic and internal parameters of the Lombardini LGW 702 engine operating on synthesis gas. The composition of the synthesis gas is based on plasma-assisted municipal waste gasification technology, or on waste gasification technology, in which air is used as a gasification agent. The mass lower heating value of the gases was in the range of 4.6 to $8 \mathrm{MJ} / \mathrm{kg}$. From the authors' experience, it can also be stated in advance that reducing the volume of inert gases $\mathrm{CO}_{2}$ and $\mathrm{N}_{2}$ below $25 \%$ with a simultaneous increase of $\mathrm{H}_{2}$ above $25 \%$ causes abnormal combustion, especially in the form of knocking and backfire of the mixture in the intake manifold. The way how to eliminate such side effects is in particular to change the method of preparation of the mixture. In addition to reducing the effects of abnormal combustion, direct fuel injection also improves the volumetric efficiency of the engine, because not the mixture but only clean air enters the engine through the intake valve. In this way, it is possible to increase the filling of the cylinder and the associated effective efficiency of the engine $[12,13]$. Another way how to prevent side effects can be rising the content of inert gases or methane. However, mixing inert gases reduces the lower heating value of the fuel, which ultimately has a negative effect mainly on the performance parameters of the engine.

Tab. 1: Physical and chemical properties of methane $\left(\mathrm{CH}_{4}\right)$ and synthesis gases (SG), (LHV - lower heating value of fuel, A/F - air to fuel ratio, $\mathrm{M}-$ molar mass, $\rho_{\mathrm{NTP} \text { fuel }}-$ density of fuel at NTP, $\mathrm{LHV}_{\text {mixture }}$ - volumetric heating value of stoichiometric mixture, NTP $=20^{\circ} \mathrm{C}, 101325 \mathrm{~Pa}$ )

\begin{tabular}{|c|c|c|c|c|c|c|c|c|c|}
\hline Parameter & Unit & $\mathrm{CH}_{4}$ & $S G 1$ & $S G 2$ & SG3 & SG4 & SG5 & SG6 & SG7 \\
\hline $\mathrm{CH}_{4}$ & [\% vol.] & 100 & 0 & 0 & 0 & 0 & 0 & 0 & 0 \\
\hline $\mathrm{H}_{2}$ & [\% vol.] & 0 & 20 & 20 & 20 & 15 & 20 & 15 & 30 \\
\hline $\mathrm{CO}$ & [\% vol.] & 0 & 35 & 30 & 40 & 60 & 55 & 65 & 10 \\
\hline $\mathrm{CO}_{2}$ & [\% vol.] & 0 & 40 & 15 & 30 & 25 & 25 & 20 & 10 \\
\hline $\mathrm{N}_{2}$ & [\% vol.] & 0 & 5 & 35 & 10 & 0 & 0 & 0 & 50 \\
\hline$L H V$ & {$[\mathrm{MJ} / \mathrm{kg}]$} & 50.012 & 5.046 & 5.287 & 5.851 & 7.336 & 7.605 & 8.066 & 4.620 \\
\hline$L H V$ & {$\left[\mathrm{MJ} / \mathrm{m}^{3}\right]$} & 33.353 & 6.128 & 5.542 & 6.717 & 8.574 & 8.476 & 9.159 & 4.190 \\
\hline A/F ratio & {$[\mathrm{kg} / \mathrm{kg}]$} & 17.12 & 1.29 & 1.36 & 1.49 & 1.83 & 1.92 & 2.02 & 1.26 \\
\hline$M$ & {$[\mathrm{~g} / \mathrm{mol}]$} & 16.04 & 29.21 & 25.21 & 27.61 & 28.11 & 26.81 & 27.31 & 21.81 \\
\hline SG in AIR & [\% vol.] & 9.5 & 43.4 & 45.7 & 41.2 & 35.9 & 35.9 & 34.4 & 51.2 \\
\hline pNTP fuel & {$\left[\mathrm{kg} / \mathrm{m}^{3}\right]$} & 0.667 & 1.214 & 1.048 & 1.148 & 1.169 & 1.115 & 1.135 & 0.907 \\
\hline oNTPmixture & {$\left[\mathrm{kg} / \mathrm{m}^{3}\right]$} & 1.152 & 1.208 & 1.132 & 1.180 & 1.191 & 1.172 & 1.180 & 1.052 \\
\hline$L H V_{\text {mixture }}$ & {$\left[\mathrm{MJ} / \mathrm{m}^{3}\right]$} & 3.172 & 2.658 & 2.533 & 2.769 & 3.081 & 3.045 & 3.146 & 2.146 \\
\hline
\end{tabular}

The following table (Tab. 1) is providing a basic overview of the properties of methane and selected methane-free synthesis gases. The most important parameter that determines the expected performance characteristics of the engine is the volumetric lower heating value of the stoichiometric mixture $\left(\mathrm{LHV}_{\text {mixture }}\right)$. Other parameters that affect the output power parameters include the rate of heat release and, last but not least, the volume of burns. SG7 
synthesis gas has the lowest heating value of the mixture (a decrease of this parameter is about $33 \%$ compared to methane) and, at the same time, it has the highest proportion of hydrogen ( $30 \%$ by volume).

\section{Experimental methods}

All experiments were performed on a Lombardini LGW 702 spark ignition internal combustion engine. It is a non-supercharged, two-cylinder, water-cooled internal combustion engine with a displacement of $686 \mathrm{~cm}^{3}$ designed to drive a micro-cogeneration unit [14]. A scheme of the experimental unit with a description of its individual components is shown in Fig. 1.

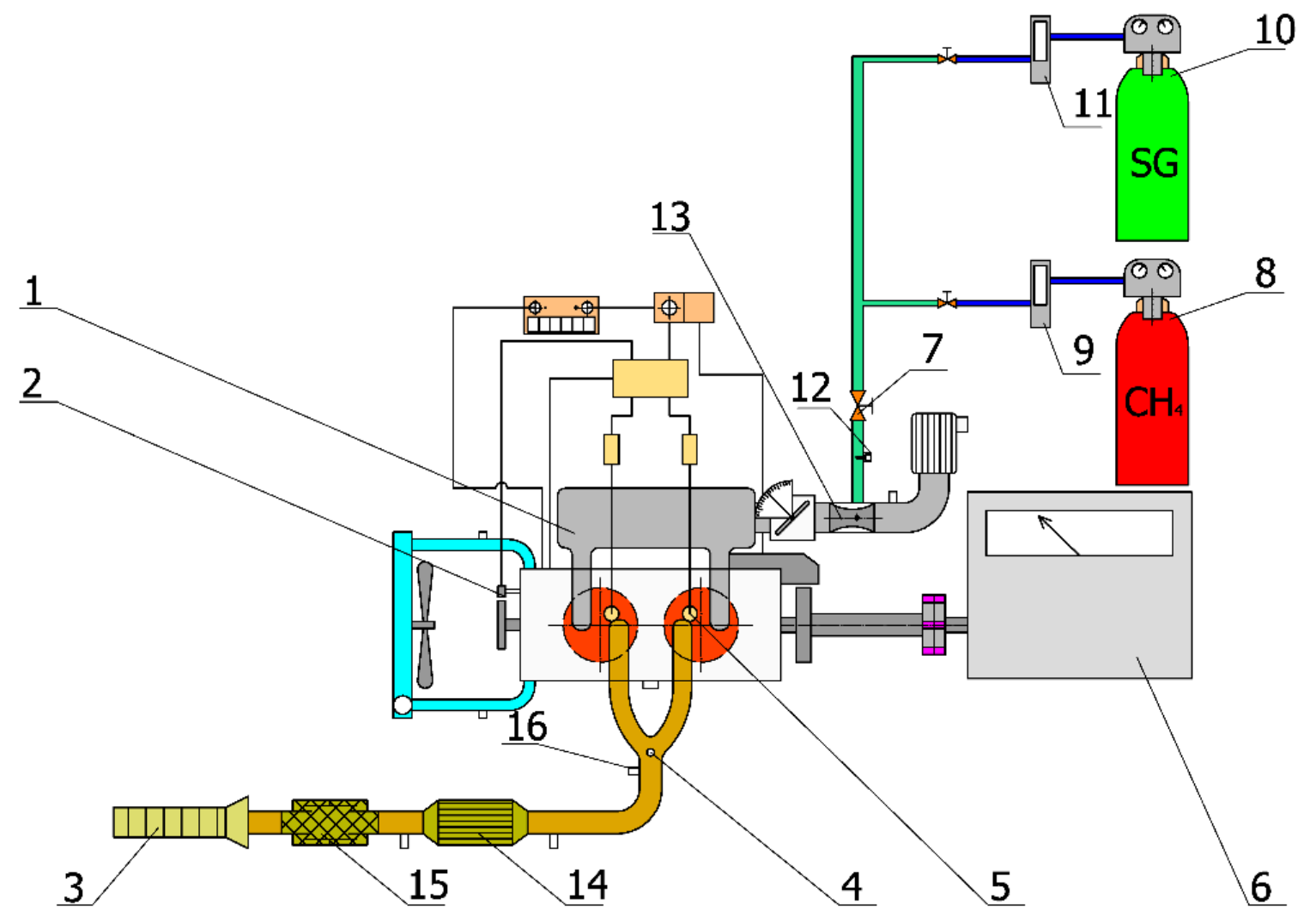

Fig. 1: The basic scheme of the combustion engine LGW 702

(1 - intake manifold, 2 - position sensor of the crankshaft, 3 - exhaust system,

4 - exhaust temperature sensor, 5 - spark plug with integrated pressure sensor, 6 - dynamometer, 7 - mixture richness regulation, 8 - pressure bottle of methane,

9,11 - mass flowmeter of gas, 10 - pressure bottle of synthesis gas,

12 - stepper motor, 13 - mixer with diffuser, 14 - catalyst, 15 - silencer, 16 - broadband lambda-probe)

The LGW 702 combustion engine was braked with an electric induction dynamometer MEZ Vsetín 1DS $736 \mathrm{~V}$. The mass flow of gases was measured with a Bronkhorst F-113ACM50-AAD-55-V flow meter. The internal combustion engine was equipped with a mixture richness control on the basis of feedback control by means of a broadband lambda-probe and a stepper motor that regulates gas flow to the mixer. The measurement of the pressure in the cylinder of the internal combustion engine was detected by means of a combined piezoelectric pressure sensor integrated in the Kistler 6118CC-4CQ02-4-1 spark plug. A Kistler 4075A10 piezo-resistive absolute pressure sensor was fitted in the intake manifold to correct the dynamic pressure profile. A correction method was used based on a comparison of the 
pressures around the bottom dead centre (BDC) at the time of opening the intake valve. The actual position of the crankshaft was detected by a Kistler 2613B1 encoder. The value of the real pre-ignition angle was also read into the collection module by means of a self-developed sensor based on the principle of optic-sensor with a diode that was connected parallel with combined BOSCH P65-T ignition coils with a maximum spark energy of $65 \mathrm{~mJ}$. The program for processing and analysis of pressure profiles was created in the Matlab program $[15,16]$.

The analysis of internal parameters was based on a single-zone zero dimensional thermodynamic model [17]. The model is created for a closed system with respect to the law of conservation of energy. The analysis of the course of heat release (fuel burning-out process) is based on the Rassweiler-Withrow method. This method is based on the fact that the pressure increase in the cylinder consists of a partial increase from the combustion itself and a partial increase from the movement of the piston in the cylinder. In general, the following relationship is used (1):

$$
d U=d Q-d W+\sum_{i} h_{i} \cdot d m_{i}
$$

Where:

$d U$ - change of internal energy of matter in the system

$d Q$ - heat delivered to the system

$d W$ - the work produced by the system

hi.dmi - $i$-th component of enthalpy of mass flow across system boundaries

The beginning and end of the energy supply in the form of combustion is determined by the entropy change method and at the same time is verified in a logarithmic $\mathrm{p}-\mathrm{V}$ diagram based on the deviation of the combustion curve from the compression or expansion line. From the measured continuous pressure profile (approx. 197 cycles at $1500 \mathrm{rpm}$ ), a statistical analysis is made in the form of an evaluation of the coefficient of variation (COV). It is calculated as the ratio of standard deviation to arithmetic mean value of the examined parameter. The cycle variability deals with the uniformity of engine operation as well as the overall lifetime of the internal combustion engine and it also affects the engine performance parameters.

The following figure (Fig. 2) shows the course of the torque in the main speed characteristic of the internal combustion engine, together with the course of the hourly fuel consumption during operation on various gaseous fuels. As can be seen, the largest decrease in torque for SG1 synthesis gas at an engine operating speed of $1500 \mathrm{rpm}$ is $12.3 \mathrm{~N} . \mathrm{m}$, i.e. 29 $\%$ compared to methane (its torque value is $42.2 \mathrm{~N} . \mathrm{m}$ ). On the contrary, the lowest decrease in torque by 7.8 N.m, i.e. by $19 \%$ compared to the methane operation, was recorded for SG6 synthesis gas that also has the highest volumetric lower heating value of the mixture out of all investigated synthesis gases. From comparison of the hourly fuel consumption it can be seen that this parameter increases for all synthesis gases due to the high percentage of fuel in the stoichiometric mixture with air. Approximately $9.5 \%$ vol. of methane fuel is required for combustion of its stoichiometric mixture, but for combusting synthesis gas this value ranges from $34.5 \%$ for SG6 up to $51.2 \%$ vol. for gas marked SG7. Due to higher density of the SG1 fuel mixture $\left(1.208 \mathrm{~kg} / \mathrm{m}^{3}\right)$, the hourly mass fuel consumption will be higher than the consumption of fuel with SG7 gas $\left(1.052 \mathrm{~kg} / \mathrm{m}^{3}\right)$, even though the volume amount of SG7 fuel in the stoichiometric mixture is by $7.8 \%$ higher compared to gas SG1. Specifically, at the speed of $1500 \mathrm{rpm}$, the highest hourly consumption is in operation on gas marked SG1 (12 
$\mathrm{kg} / \mathrm{h}$ ) and, conversely, the lowest consumption is in operation on gas SG6 $(9.1 \mathrm{~kg} / \mathrm{h})$. Compared to methane, the increase in consumption is 6 to 8 times higher for synthesis gases.

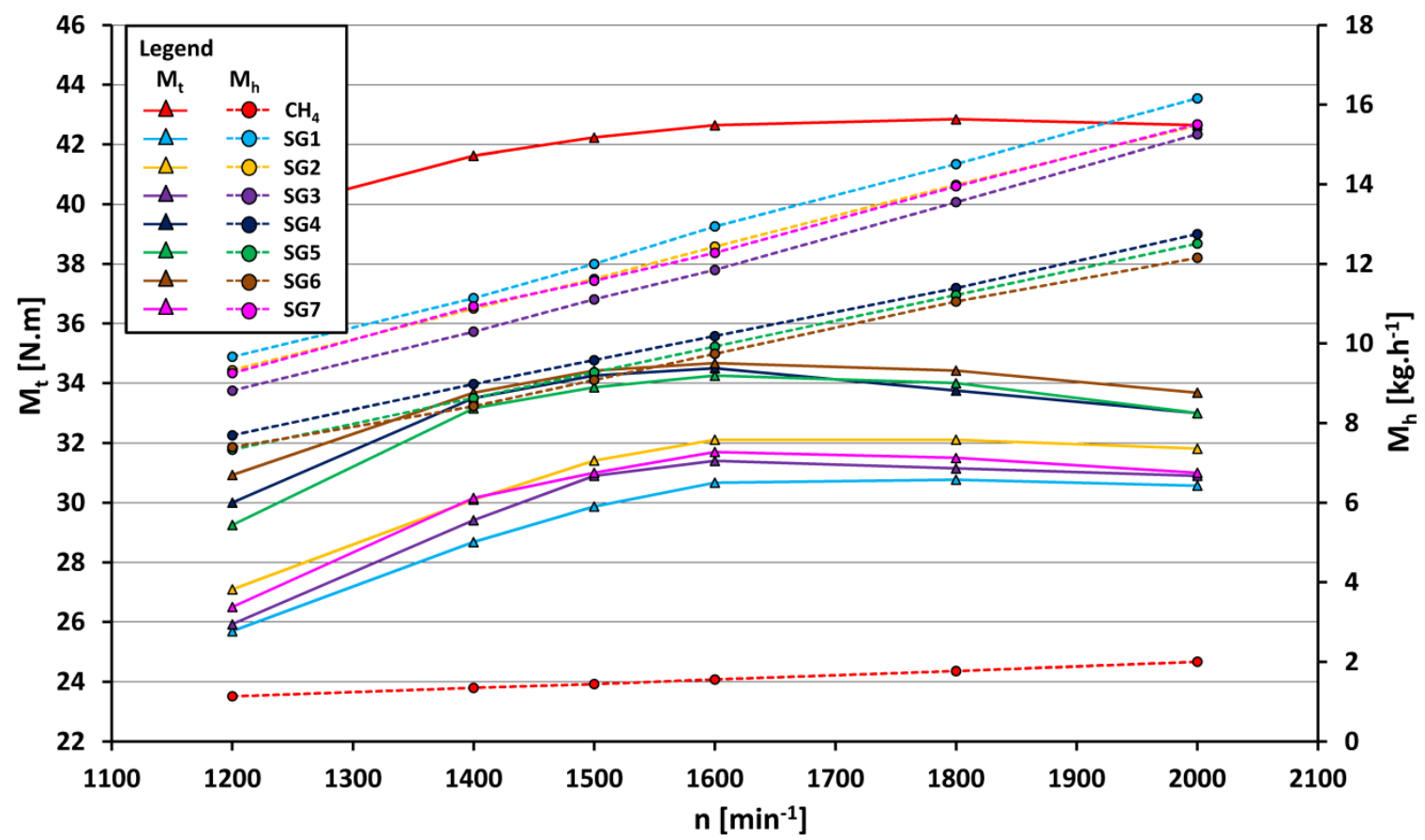

Fig. 2: Course of break torque $\mathrm{M}_{t}$ and hourly fuel consumption $\mathrm{M}_{\mathrm{h}}$ in the engine speed characteristics for methane and synthesis gases at full load, for stoichiometric mixture and optimum SOI angle

Fig. 3 represents the course of the indicated mean effective pressure (IMEP) as a function of the angle at which $50 \%$ of the fuel is burned. The graph was prepared from measurements at different SOI values, with approximately 197 cycles recorded for one SOI value. The highest IMEP value $(0.965 \mathrm{MPa})$ was found in methane combustion. The angle at which $50 \%$ of the fuel is burned for this IMEP is approximately $8.6{ }^{\circ} \mathrm{CA}$ ATDC. Out of the synthesis gases, the highest IMEP value $(0.750 \mathrm{MPa})$ was reached by gases marked SG4 and SG5 (angle $\alpha_{50 \% \mathrm{MFB}}$ has a value of about $5.5{ }^{\circ} \mathrm{CA}$ ATDC for both gases) and, conversely, the lowest IMEP value (0.680 MPa) was found when burning gas marked SG1, at which the angle $\alpha_{50 \mathrm{MFB}}$ is approx. $5.7^{\circ} \mathrm{CA}$ ATDC. If the coefficient of variation (COV) for IMEP at the optimum SOI angle was compared, then for methane combustion this parameter was approximately $0.58 \%$. The lowest value of $\mathrm{COV}_{\text {IMEP }}$ for synthesis gases was found when burning gas SG2 $(0.45 \%)$ and, conversely, the highest value was found when the engine was operating on gas marked SG6 (2.24\%).

Figure Fig. 4 shows the course of the pressure $(p)$ in the cylinder during the compression and expansion phase of the gas as a function of the crankshaft rotation angle $(\alpha)$. The curves represent the average measured values of pressures at optimum SOI angle for synthesis gases and methane. When burning methane, the highest value of maximum pressure (6.04 MPa) has been reached at the angle of $12.8^{\circ} \mathrm{CA}$ ATDC. Out of the synthesis gases, the synthesis gases SG4 and SG5 have the highest maximum pressure value $5.7 \mathrm{MPa}$ at the angle of 10.5 and $10.9{ }^{\circ} \mathrm{CA}$ ATDC, respectively. This character of the pressure course was also reflected in the mentioned IMEP value that was the same for both gases. The lowest value of the maximum pressure (4.95 $\mathrm{MPa})$ was recorded during the combustion of synthesis gas designated SG3. The course of the pressure of the synthesis gas SG1 marks the largest negative area before TDC and the smallest positive area after TDC which results in the lowest IMEP value $(0.680$ 
$\mathrm{MPa}$ ). The COV value for maximum pressure has the highest value $7 \%$ for synthesis gas SG1 and, conversely, the lowest value $3.6 \%$ is for the fuel marked SG7. The reference fuel methane has a value of the COV for maximum pressure $6.8 \%$.

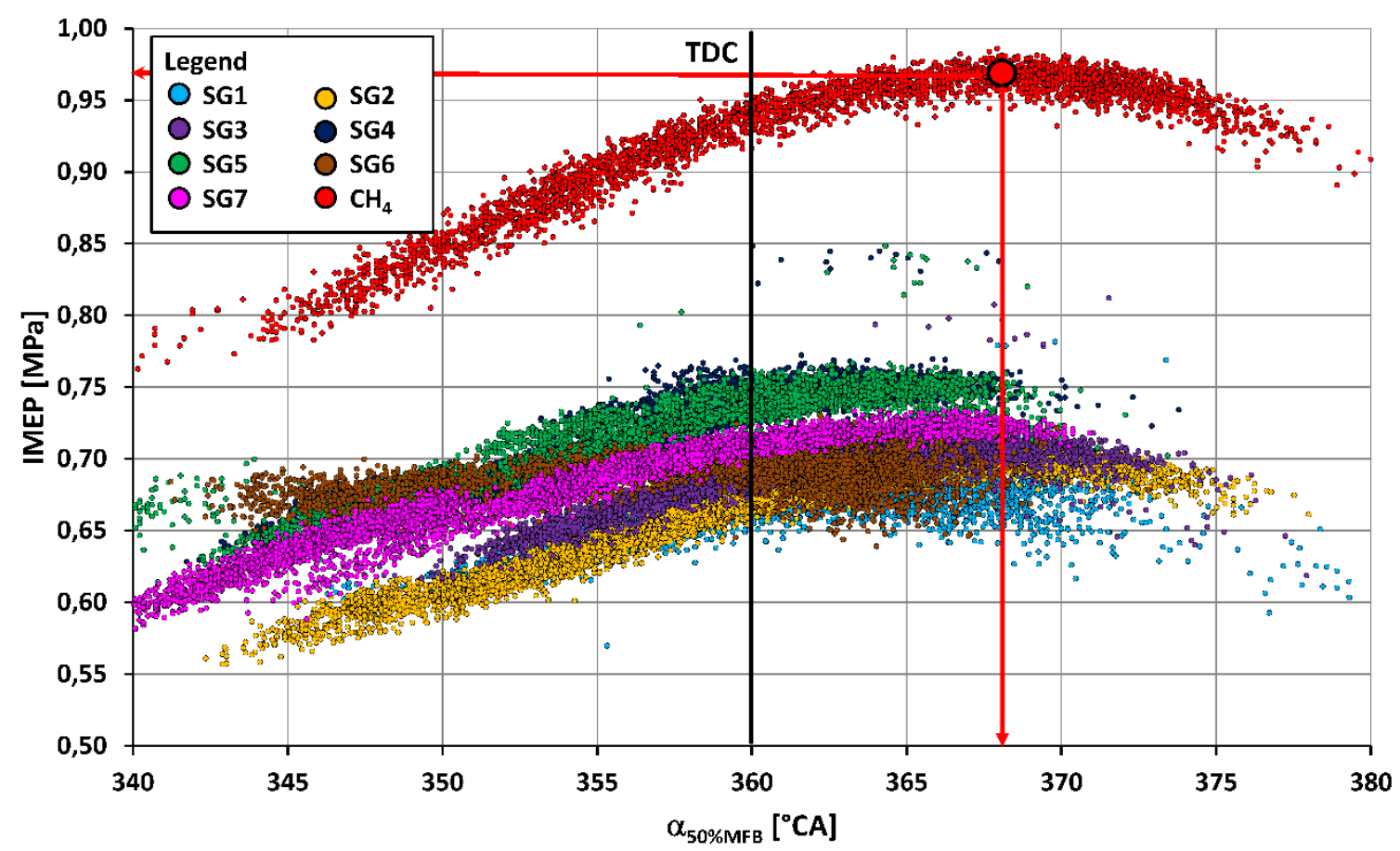

Fig. 3: The course of the indicated mean effective pressure (IMEP) as a function of the crankshaft rotation angle $\left({ }^{\circ} \mathrm{CA}\right)$, when $50 \%$ of weight of the fuel $\left(\alpha_{50 \% \mathrm{MFB}}\right)$ is burned during the combustion of methane and synthesis gases. Conditions: $1500 \mathrm{rpm}$, full load, stoichiometric mixture

The value of pressure raise rate for the reference fuel (methane) was $0.225 \mathrm{MPa} / 1^{\circ} \mathrm{CA}$. When comparing synthesis gases, the highest pressure raise rate value $\left(0.244 \mathrm{MPa} / 1{ }^{\circ} \mathrm{CA}\right)$ was recorded when the engine was operating on SG5 gas, which is due to a higher proportion of hydrogen ( $20 \% \mathrm{vol}$.) and, at the same time a lower proportion of inert gases (25\%vol.). A similar value of pressure raise rate $\left(0.242 \mathrm{MPa} / 1^{\circ} \mathrm{CA}\right)$ is achieved by burning SG7 gas, which contains up to $30 \%$ vol. hydrogen. Due to the high proportion of inert gases (up to $60 \%$ vol.), this value of pressure raise rate does not increase radically. The lowest values of pressure raise rate $\left(0.2 \mathrm{MPa} / 1{ }^{\circ} \mathrm{CA}\right)$ were achieved in combustion of synthesis gases SG1, SG2 and SG3. These gases had a constant proportion of hydrogen (20\% vol.) and a relatively large proportion of inert gases that slow down the combustion process and as a follow-up they lead to a less sharp increase in pressure. 


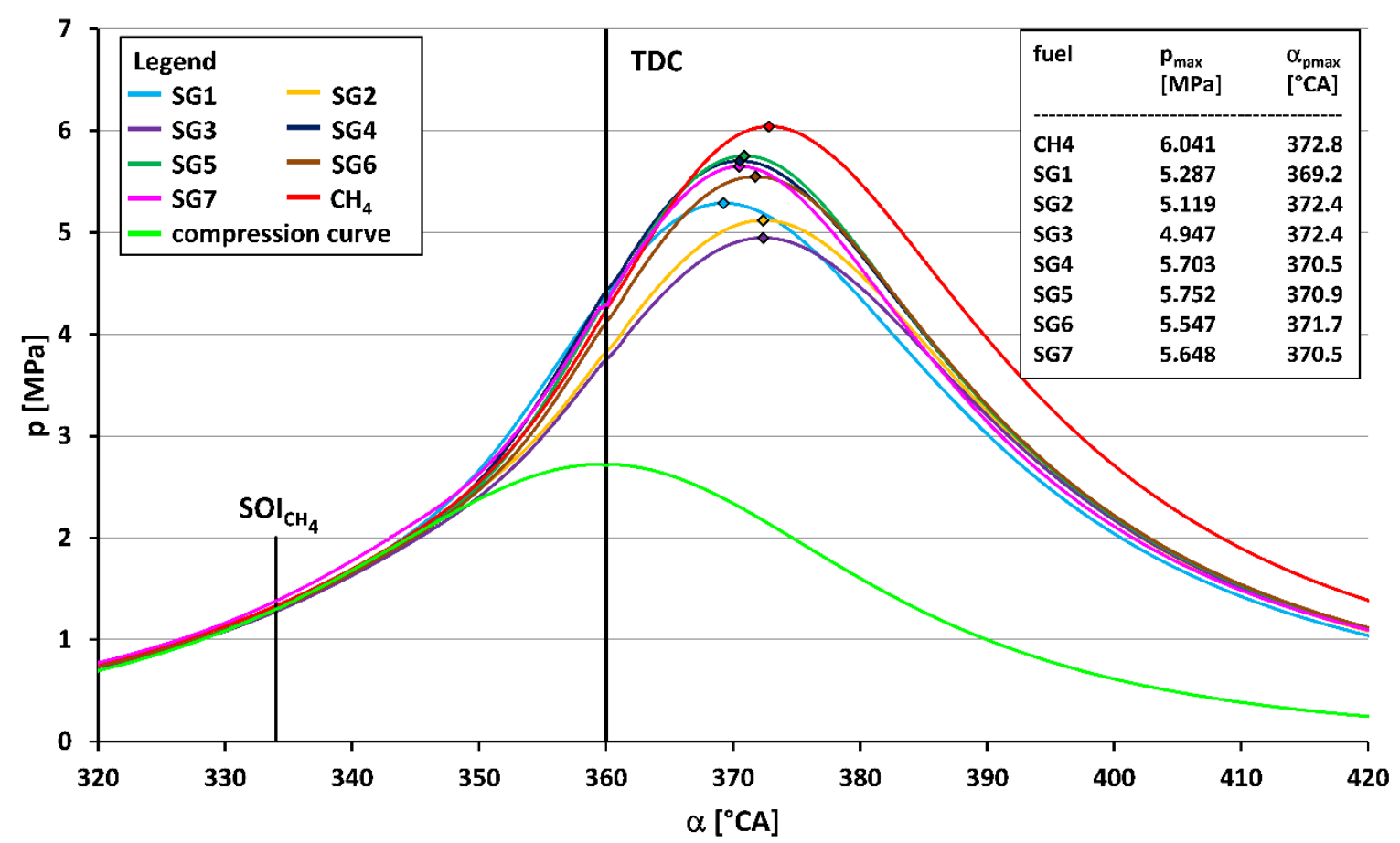

Fig. 4: Course of pressure $p$ in the cylinder of an internal combustion engine during operation on methane and synthesis gases depending on crankshaft angle $\alpha$. Conditions: $1500 \mathrm{rpm}$, full load, stoichiometric mixture, optimum start of ignition (SOI) angle for each fuel, compression curve is measured for air.

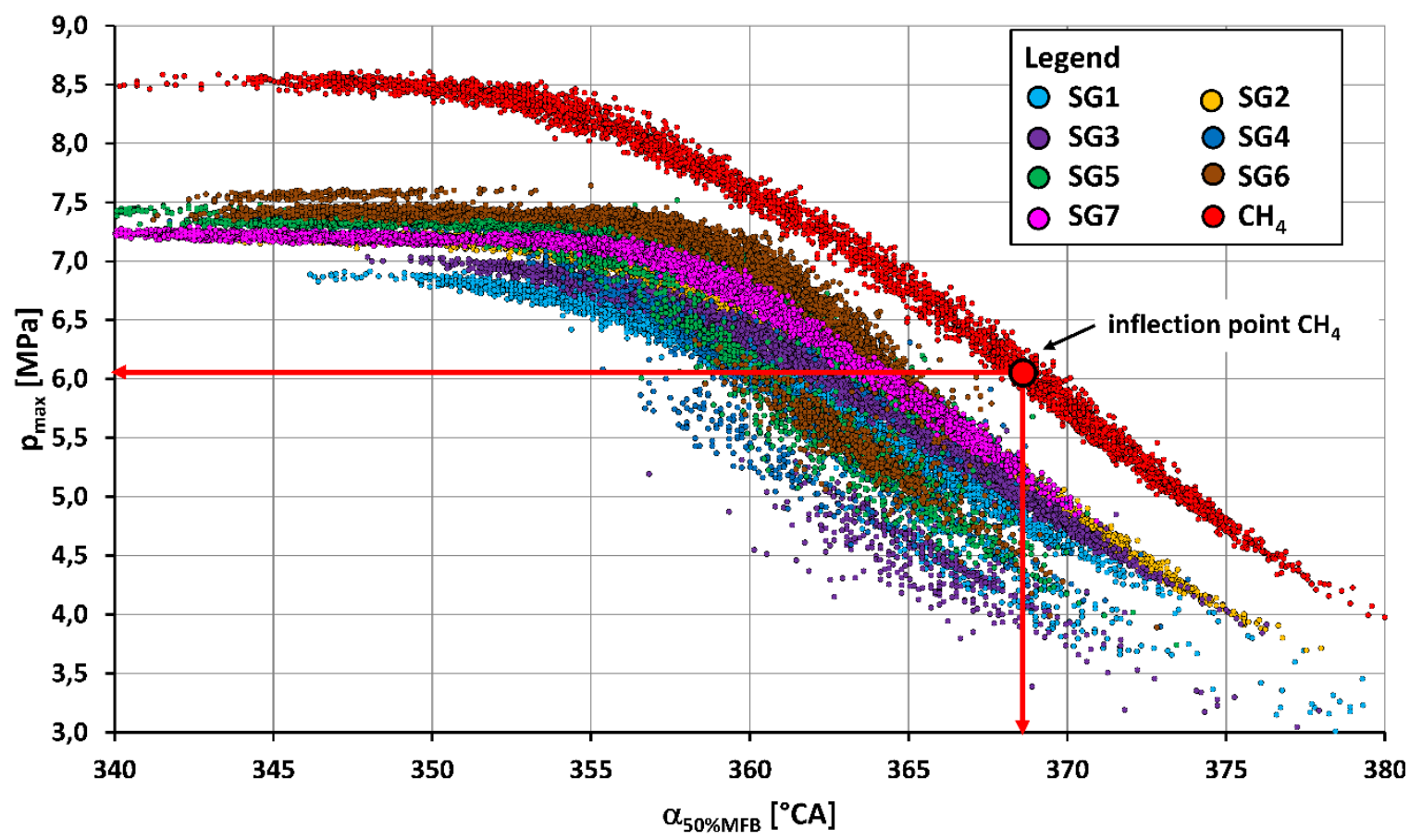

Fig. 5: Course of the maximum pressure $p_{\max }$ depending on the angle $\alpha_{50 \% \mathrm{MFB}}$ at which $50 \%$ of the fuel for methane and synthesis gases is burned. Conditions: $1500 \mathrm{rpm}$, full load, stoichiometric mixture

Figure 5 shows the course of the maximum pressure as a function of the angle at which 50 $\%$ by weight of the fuel is burned. For each of the fuels a control characteristic was measured in which the SOI value varied from approx. $15{ }^{\circ} \mathrm{CA}$ BTDC to $40{ }^{\circ} \mathrm{CA}$ BTDC (197 cycles 
were recorded for each SOI), then a graph Fig.5 was constructed. As can be seen from the graph, the maximum pressure is stable at approx. 8.5 MPa and increasing SOI does not significantly change the maximum pressure. The course of the maximum pressure as a function of the angle $\alpha_{50 \% \mathrm{MFB}}$ is $\mathrm{S}$-shaped. The location of the inflection point for methane has coordinates for maximum pressure $6.1 \mathrm{MPa}$ at $8.5^{\circ} \mathrm{CA}$ ATDC. The inflection point of the Scurve is located in the graph at the point where the internal combustion engine operates with the optimum SOI angle $\left(26^{\circ} \mathrm{CA}\right.$ BTDC for methane) and thus at which the engine reaches the highest IMEP value. The lowest curve of maximum pressure relates to the synthesis gas SG1 that has also the lowest performance parameters. Each S-curve always has a different inflection point for a given gas at an angle of $\alpha_{50 \% \mathrm{MFB}}$, when the highest power parameters of the engine with this gas are achieved. In other words, the inflection point for a given gas is always located at the place where the internal combustion engine works with the optimum SOI angle.

The last figure (Fig. 6) shows the fuel burn-out (MFB) as a function of the crankshaft rotation angle for different compositions of the synthesis gas mixture compared to methane.

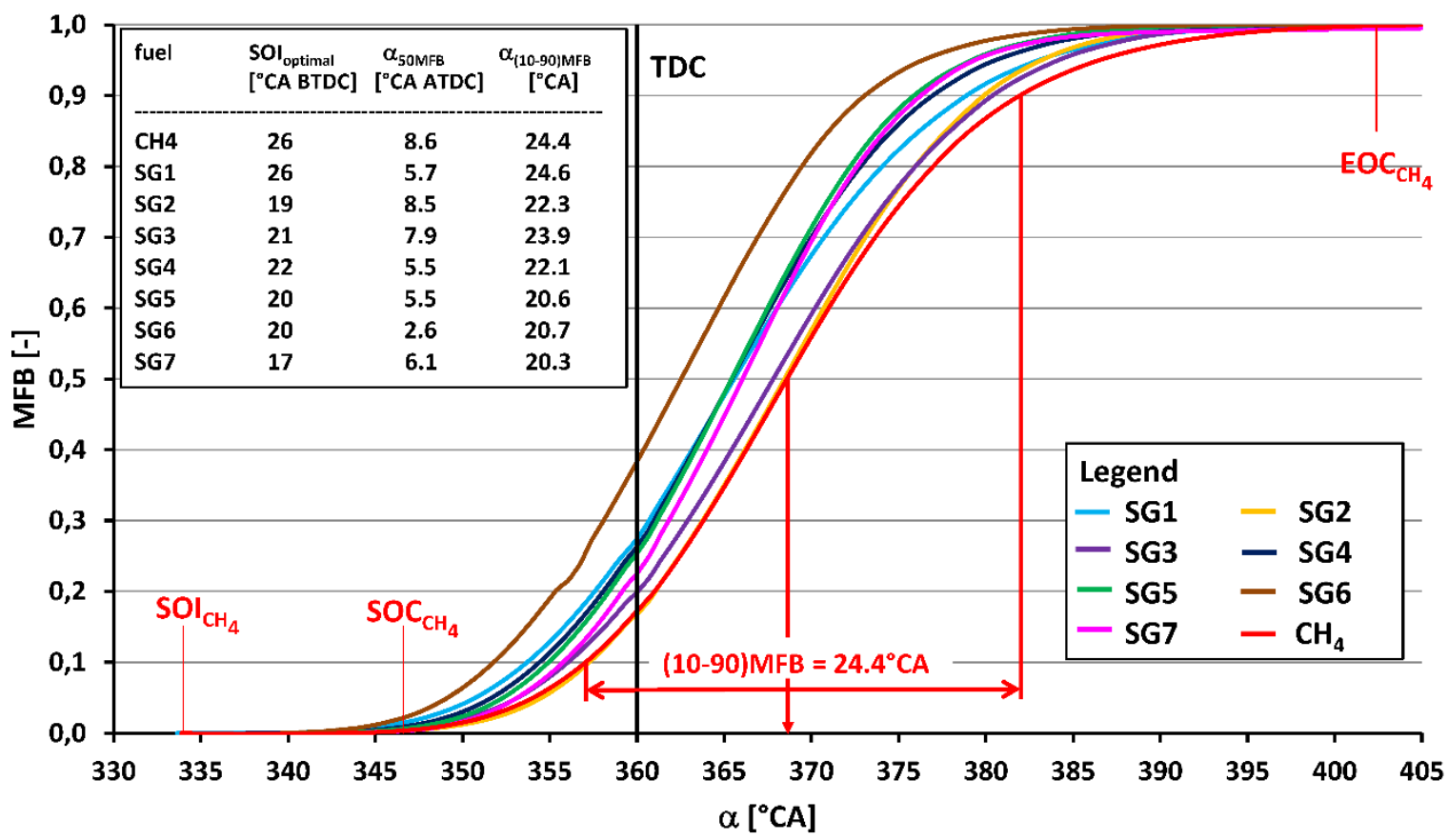

Fig. 6: Course of burning-out of fuel as dependent on the crankshaft angle for methane and synthesis gases (MFB - mass fraction burned, $\alpha$ - crankshaft rotation angle, TDC - top dead centre, SOI - start of ignition, SOC - start of combustion, EOC - end of combustion). Conditions: $1500 \mathrm{rpm}$, full load, stoichiometric mixture, optimum SOI angle for each fuel

From the course of methane burning-out process, it can be seen that the angle at which 50 $\%$ of the fuel is burned $\left(8.6^{\circ} \mathrm{CA}\right.$ ATDC) corresponds to the position of the inflection point (Fig. 5), which corresponds to the engine operation at optimum SOI angle (26 ${ }^{\circ} \mathrm{CA}$ BTDC). The ignition delay (time interval between start of ignition (SOI) and visible start of combustion moment (SOC)) for methane is around $12.5^{\circ} \mathrm{CA}$. The time interval between SOI and burning-out $5 \%$ of fuel by weight is approximately $20.4{ }^{\circ} \mathrm{CA}$. The main combustion time interval $(10-90 \% \mathrm{MFB})$ lasts $24.4^{\circ} \mathrm{CA}$. The overall burning time interval for methane (time interval between SOC and EOC) is $56{ }^{\circ} \mathrm{CA}$. Out of the synthesis gases, the longest main 
combustion time interval $\left(24.6{ }^{\circ} \mathrm{CA}\right)$ has the synthesis gas with the designation SG1. The SG7 synthesis gas has the shortest main combustion time interval $\left(20.3{ }^{\circ} \mathrm{CA}\right)$ due to the high hydrogen content in the mixture. The time interval between the moment of SOI and the angle at which $5 \%$ of the fuel is burned is the shortest $\left(9.9{ }^{\circ} \mathrm{CA}\right.$ and $\left.10.3{ }^{\circ} \mathrm{CA}\right)$ when burning SG6 and SG7 synthesis gases, respectively. The longest time interval $\left(17.3{ }^{\circ} \mathrm{CA}\right)$ has been measured with fuel marked SG1. The coefficient of variation of the angle position (COV $\alpha$ ), at which a given mass fraction of fuel is burned, generally increases with increasing proportion by mass of fuel burned. For methane, these values are as follows: $\mathrm{COV}_{\alpha 10 \% \mathrm{MFB}}=0.36 \%$, $\mathrm{COV}_{\alpha 50 \% \mathrm{MFB}}=0.53 \%, \mathrm{COV}_{\alpha 90 \% \mathrm{MFB}}=0.71 \%$. When burning synthesis gases, the highest values $\mathrm{COV}$ in the whole range has the synthesis gas marked SG1 $\left(\mathrm{COV}_{\alpha 10 \% \mathrm{MFB}}=0.38 \%\right.$, $\left.\mathrm{COV}_{\alpha 50 \% \mathrm{MFB}}=0.62 \%, \mathrm{COV}_{\alpha 90 \% \mathrm{MFB}}=0.96 \%\right)$. The synthesis gas with the designation SG7 has the lowest values of $\operatorname{COV}\left(\operatorname{COV}_{\alpha 10 \% \mathrm{MFB}}=0.19 \%, \mathrm{COV}_{\alpha 50 \% \mathrm{MFB}}=0.30 \%, \mathrm{COV}_{\alpha 90 \% \mathrm{MFB}}=\right.$ $0.37 \%)$, which is due to the high proportion of hydrogen in the fuel.

\section{CONCLUSIONS}

Synthesis gas as a source of fuel from renewable energy sources can be an important source of propulsion for internal combustion engines in stationary applications (cogeneration units). The use of this type of fuel contributes to reducing the carbon footprint of the environment. The most important parameter of synthesis gases, which influences the performance parameters of the engine, is their volumetric lower heating value of the stoichiometric mixture. In the second place, the actual process of burning the mixture must be taken into account. This process is influenced by the value of SOI for the individual powering gases, the ignition delay, the burning rate of the mixture, the volume change of the combustion products, the differences in the expansion of the individual gases, and the like. All these aspects and parameters that characterize the combustion process, together with the perfection of filling the cylinder with air or fresh mixture characterized by volumetric efficiency, also affect the resulting value of the effective efficiency of the engine. The following is a brief summary of the results about the influence of methane-free synthesis gases on the parameters of the internal combustion engine in comparison with the engine operating on methane at the operating speed $1500 \mathrm{rpm}$ :

- the angle of optimum start of ignition (SOI) ranged from $17^{\circ} \mathrm{CA}$ BTDC for SG7 (due to the high proportion of hydrogen that burns the fastest) up to $26^{\circ} \mathrm{CA}$ BTDC for SG1 synthesis gas and for methane;

- the torque value for the reference fuel methane was 42.2 N.m and all examined synthesis gases had a lower torque value (from 29.9 N.m for SG1 to 34.4 N.m for SG6). It is given by the fact that the volumetric lower heating value of the mixture was lower for all synthesis gases compared to methane;

- the hourly fuel consumption of the synthesis gases was 6 to 8 times higher than in methane operation, because in the synthesis gases operation a small amount of air is consumed to form a stoichiometric mixture (from $1.3 \mathrm{~kg} / \mathrm{kg}$ for $\mathrm{SG} 7$ to $2.0 \mathrm{~kg} / \mathrm{kg}$ for SG6) compared to methane $(17.1 \mathrm{~kg} / \mathrm{kg})$;

- the largest decrease in the value of indicated mean effective pressure IMEP (by $29.5 \%$ ) was recorded during operation on the SG1 synthesis gas (0.680 MPa) compared to methane $(0.965 \mathrm{MPa})$. On the contrary, out of the synthesis gases analysed the least decrease (by $22 \%$ ) occurred during operation on synthesis gases designated SG5 and SG6 (0.750 MPa) that had the highest mass lower heating value of the fuel (7.605 and $8.066 \mathrm{MJ} / \mathrm{kg}$, respectively); 
- the maximum pressure in the cylinder was the highest (6.04 MPa) during methane combustion. The synthesis gas marked SG3 had the lowest value of maximum pressure (4.95 MPa). On the contrary, the highest values of maximum pressure in the synthesis gases were reached during operation on SG4 and SG5, when the value of maximum pressure was 5.7 and $5.75 \mathrm{MPa}$, respectively. The coefficient of maximum pressure variation had the lowest value in operation on synthesis gas SG7 (3.6\%). On the contrary, the highest value was measured in operation on SG1 (6.9\%);

- the lowest value of pressure rise rate was measured in operation on synthesis gases from SG1 to SG3 $\left(0.2 \mathrm{MPa} / 1^{\circ} \mathrm{CA}\right)$. These mixtures contained a relatively large amount of inert gases. Those synthesis gases that contained a large amount of hydrogen (20 $\%$ vol. in SG5 and $30 \%$ vol. in SG7) also reached the highest values of pressure rise rate $\left(0.24 \mathrm{MPa} / 1^{\circ} \mathrm{CA}\right)$;

- the analysis of the course of fuel combustion shows that the longest main combustion time interval (10-90\% MFB) occurs when burning the SG1 synthesis gas and is represented by the value of $24.6{ }^{\circ} \mathrm{CA}$. The shortest main combustion time interval $(20.3$ ${ }^{\circ} \mathrm{CA}$ ) is characteristic of SG7 fuel that contains a high proportion of hydrogen in the mixture (30\%vol.). The angle at which half of the fuel was burned ranged from 2.6 ${ }^{\circ} \mathrm{CA}$ ATDC for SG6 up to $8.5^{\circ} \mathrm{CA}$ ATDC for SG2 (for methane the value is $8.6{ }^{\circ} \mathrm{CA}$ ATDC). The time interval between SOI and burning-out $5 \%$ of fuel by weight (SOI$5 \%$ MFB) was the shortest $\left(9.9^{\circ} \mathrm{CA}\right.$ and $\left.10.3{ }^{\circ} \mathrm{CA}\right)$ when the engine was operating on the SG6 and SG7 synthesis gases, respectively. Vice versa, the longest time interval (SOI-5\% MFB) was found $17.3^{\circ} \mathrm{CA}$ with the synthesis gas SG1. The coefficients of variation $(\mathrm{COV})$ of the position of individual points during the fuel burning-out process were the lowest for synthesis gas SG7 and the highest for synthesis gas SG1. These $\mathrm{COV}$ values for all synthesis gases used are comparable with the values for methane. They characterise highly stable combustion processes in the engine cylinder and are similar to the values of the above-mentioned reference fuel methane.

The results presented in the article and summarized in the conclusions give an idea of both the external (torque and engine consumption) but mostly of the internal parameters of the engine, which relate to the combustion process of low-energy methane-free synthesis gases. The parameters of these gases little differ from the internal parameters of methane combustion in an internal combustion engine, so we can consider these gases to be a quality fuel for the internal combustion engine. Synthesis gases as fuels have the potential to reduce the adverse impact of greenhouse gases on the environment. Moreover, synthesis gas fuel applications can address the issue of municipal waste by significant reduction of landfilling.

\section{ACKNOWLEDGEMENT}

This work was supported by the Slovak Research and Development Agency under Contract No. APVV-17-0006, APVV-18-0023 and was also supported by the Slovak Scientific Grant Agency under the Contracts No. VEGA 1/0301/17, KEGA 026STU-4/2018 and KEGA 041STU-4/2020. Translator to English: Veronika Polóniová, Slovak University of Technology in Bratislava.

\section{REFERENCES}

[1] Lieskovská, Z., Lényiová, P. editors "Spáva o stave životného prostredia Slovenskej republiky v roku 2018", Ministerstvo životného prostredia Slovenskej republiky, Bratislava, ("Report on the state of the environment of the Slovak Republic in 2018", 
Ministry of the Environment of the Slovak Republic, Bratislava, 2019), 2019. ISBN 978-80-8213-007-5.

[2] Higman, Ch. "State of the Gasification Industry - the Updated Worldwide Gasification Database", 2013 International Pittsburgh Coal Conference, Beijing, China, 2013.

[3] Ramos, A., Teixeira, C. A., Rouboa, A. "Environmental Assessment of Municipal Solid Waste by Two-Stage Plasma Gasification“, Energies 12 (1), 137, 2019. DOI: 10.3390/en12010137

[4] Orr, D., Maxwell, D. "A Comparison of Gasification and Incineration of Hazardous Wastes - Report”, 2000, DCN 99.803931.02

[5] De Filippis, P., Borgianni, C., Paolucci, M., Pochetti, F. "Prediction of syngas quality for two-stage gasification of selected waste feedstocks", Waste Management 24 (6), pp. 633 - 639, 2004. DOI: 10.1016/j.wasman.2004.02.014

[6] Durmusoglu, E., Corapcioglu, M. Y., Tuncay, K. "Landfill Settlement with Decomposition and Gas Generation”, Journal of Environmental Engineering 131 (9), 2005. DOI: 10.1061/ (ASCE) 0733-9372(2005)131:9(1311)

[7] Oboirien, B. O., North, B. C. "A review of waste tyre gasification", Journal of Environmental Chemical Engineering 5 (5), pp. 5169 - 5178, 2017. DOI: 10.1016/j.jece.2017.09.057

[8] Kapilan. N., Jullya, N. "Studies on Improvement of Performance of Compression Ignition Engine Fuelled with Mixture of Honge Biodiesel and Tire Pyrolysis Oil", Strojnícky časopis - Journal of Mechanical Engineering 68 (1), pp. 15 - 24, 2018. DOI: 10.2478/scjme-2018-0002

[9] Laurence, L. C., Ashenafi, D. "Syngas Treatment Unit for Small Scale Gasification Application to IC Engine Gas Quality Requirement", Journal of Applied Fluid Mechanics 5 (1), pp. 95 - 103, 2012.

[10] Bates, R. P., Dölle, K. "Syngas Use in Internal Combustion Engines - A Review", Advances in Research 10 (1), pp. 1 - 8, 2017.

[11] Milne, T. A., Evans, R. J., Abatzoglou, N. "Biomass gasifier "Tars": Their Nature, Formation and Conversion. US: National Renewable Energy Laboratory; NREL/TP570-25357, pp. 37 - 38, 1998.

[12] Duan, J., Liu, F., Sun, B. "Backfire control and power enhancement of a hydrogen internal combustion engine", International Journal of Hydrogen Energy 39 (9), pp. 4581 - 4589, 2014. DOI: 10.1016/j.ijhydene.2013.12.175

[13] MacCarley, C. A., Van Vorst, W. D. "Electronic Injection Techniques for Hydrogen Powered I. C. Engines", International Journal of Hydrogen Energy 5 (2), pp. 179 - 203, 1980. DOI: $10.1016 / 0360-3199$ (80)90095-6

[14] Chríbik, A., Polóni, M., Minárik, M. "Influence of Selected Synthesis Gas Component on Internal Parameters of Combustion Engine", Strojnícky časopis - Journal of Mechanical Engineering 69 (4), pp. 25 - 32, 2019. DOI: 10.2478/scjme-2019-0040

[15] Popardovský, V. "Optimization of Vehicle Suspension Neural Model”, In: Proc. of the 22nd International Scientific Conference TRANSPORT MEANS 2018, ISSN 1822296X, Trakai, Lithuania, pp. 1361 - 1364, 2018.

[16] Popardovský, V., Popardovská, E. "Vehicle Suspension Control Based on PID Controller Adapted by Feed-Forward Neural Network", In: Zeszyty Naukowe 
INSTITUTU POJAZDÓW, ISSN 1642-347X, , Warsaw University of Technology, pp. 99 - 107, 2017.

[17] Merker, G. P., Schwarz, Ch., Teichmann, R. "Combustion Engines Development: Mixture Formation, Combustion, Emissions and Simulation", Springer-Verlag Berlin Heidelberg, 2012. DOI: 10.1007/978-3-642-14094-5 